\title{
ADOLESCENT INVOLVEMENT IN SPORTS ACTIVITIES AND INTERNALISATION OF MORAL VALUES
}

\author{
Enrika Kromerova, Saulius Šukys \\ Lithuanian Sports University, Kaunas, Lithuania
}

\begin{abstract}
Background. Relatively little knowledge is available to date about moral values among adolescents. As participation in sports activities may contribute to positive youth development, this study aims to examine the relations between adolescents' involvement in sports activities and the internalisation of their moral values. We assessed this relationship with respect to gender as well.

Methods. The sample included 385 adolescents (192 girls and 193 boys) between 13 to 16 years of age ( $M$ age $=14.6, S D=1.11) ; 43.4 \%(n=167)$ of the research participants were involved in competitive sports. The studied adolescents had participated in their respective sport for an average of $2.97(S D=1.12)$ years. The internalisation of moral values was assessed using the 24-item adolescent-report Moral Values Internalisation Questionnaire (Hardy, Padilla-Walker, \& Carlo, 2008). Four forms of value regulation were assessed (external, introjected, identified and integrated). Overall value internalisation was also evaluated.

Results. Significant differences were found between adolescent involvement in sports activities and external regulation $(p<.05)$, introjected regulation $(p<.01)$, identified regulation $(p<.05)$ as well as integrated regulation $(p<.01)$. In depth analyses showed that the four forms of value regulations were higher for the athletes with experience up to three years and tended to be lower in the group of athletes with higher sports experience. The same relationship was established in the sample of boys, but not in that of girls.

Conclusions. The research results demonstrated that the identified regulation manifested more than other regulations did (external, introjected and integrated). Adolescent athletes possessed higher points of moral value internalisation in all regulations than adolescent non-athletes. Nevertherless, referring to sports experience, the internalisation forms of moral values of adolescent athletes with more than the three-year sport experience did not differ in comparison with those of adolescent non-athletes. Research results show that the internalisation of moral values for adolescents with higher sports experience is lower compared to that of adolescents with lower sports experience.
\end{abstract}

Keywords: adolescents' moral values, participation in sport, sports experience.

\section{INTRODUCTION}

$\mathrm{T}$ The adolescent stage is the last and most challenging stage of child's development. It is a period of formation of a person's individuality and slow stabilization of personality. This stage marks the threshold from childhood to a person's preparation for adult life. Many authors emphasize similar descriptions of adolescence giving emphasis on various peculiarities of this stage. Myers (2000) argues that adolescence is a stage between biological maturity and social independence. According to Mathur (2011), every person goes through individual and transitional period of adolescence when childhood ends and adulthood life begins. Expression of personal character traits becomes more active during adolescence because a young man or woman becomes a member of society (Timpau, 2015).

According to Hardy and Carlo (2011), adolescence is a very important stage when abstract thinking skills develop. Such skills lead to the absolute integration of moral principles and individual values (Paciello, Fida, Tramontano, 
Cole, \& Cerniglia, 2013). Moreover, qualities and skills related to moral functioning are more pronounced during adolescence (compared to childhood) when life is becoming more complex (Hardy \& Carlo, 2005). Moral self-determinations of adolescents are based on everyday life experience when they have to make certain decisions and regulate their behaviour facing new challenges and social influence (Paciello et al., 2013). Moreover, adolescents gradually progress from external (parental) to autonomous regulation of their behaviour. They become increasingly responsible for their own behaviour and choices. While pursuing a morally responsible personality, an aspect of internalisation of moral values appears to be significant because the internalisation of values is a process by which adolescents progressively accept values and integrate them into their sense of self; their behaviour becomes internally controlled or self-regulated rather than primarily externally controlled (Grolnick, Deci, \& Ryan, 1997; Grusec, 2002). Undoubtedly, the moral maturity and value system of children and adolescents are significantly influenced by parents as adolescents' value system shapes depending on how parents transfer their values to their children (Hardy et al., 2008). On the other hand, since most of the time adolescents spend at school together with their peers, they overestimate their values which potentially maintain their well-being (Barni, Ranieri, Scabini, \& Rosnati, 2014). In addition, adolescent participation in extracurricular activities affects adolescents' development in a meaningful way.

A number of studies suggest that adolescent participation in extracurricular activities encourages positive youth development (EstebanCornejo et al., 2014; Guevrement, Findlay, \& Kohen, 2014). But different types of activities may stimulate different developmental experiences. In this context, particular attention is paid to adolescent participation in sports activities. Despite the fact that participation in sport is one of the most popular forms of extracurricular activities (Vaitkevičius, Miliūnienè, \& Bakanovienè, 2008), empirical studies do not always reveal the positive impact of sport on different aspects of behavior (Blomfield \& Barber, 2010; Jankauskiene \& Sukys, 2012). On the other hand, a close link between moral education and sport is indicated (Hardman, Jones \& Jones, 2010). A number of scholars emphasize that sports activities are one of the most influencing and significant factors playing an important role in the development of personality traits and value orientations for adolescents (Budreikaite \& Adaskeviciene, 2010; Moreno \& Cervello, 2005; Popescu, 2012).

It should be noted that values were researched in the context of sporting activities. Lee and Cockman (1995) identified 18 values spontaneously expressed by young athletes in discussion of moral dilemmas in their sport. Afterwards, other researchers also sought to distinguish the essential values in sport (Lee, Whitehead, \& Balchin, 2000) identifying moral, competence and status values and their relation to achievement orientation and attitudes in youth sport (Lee, Whitehead, Ntoumanis, \& Hatzigeorgiadis, 2008). A questionnaire constructed on the basis of recent research allowed comparing athletes' values identified in different cultures (Whitehead \& Goncalves, 2013), analysing the relationship of values in sport with moral disengagement (Šukys \& Jansoniene, 2012) and prosocial behaviour in sport (Stupuris, Šukys, \& Tilindienè, 2013). Though this research focused on values identified in sports activities, it revealed some conflicts and compatibilities among basic values in sport. It is no coincidence that research aimed to compare values of athletes and nonathletes. Material and non-material traditional values of athletes and non-athletes (Perenyi, 2010), the approach to values as well as their perception were compared (Budreikaité \& Adaskevičienè, 2010). However, moral values have not been studied in the research yet. In addition, there is a lack of research where the focus would have been placed on the internalisation mechanisms of values, especially moral values.

Describing values as motivational in their function (Schwartz, 1994) and understanding internalisation as integration of values into one's self that emphasizes self-regulation rather than external control (Grolnick et al., 1997; Grusec, 2002) highlights the importance of SelfDetermination Theory (Deci \& Ryan, 1990). According to this theory, each person is willing to engage in certain activity, however, when a person faces obstacles, he or she may lose motivation and become passive (Deci \& Ryan, 1990). In SelfDetermination Theory four forms of human value regulation are identified: external regulation (when behaviour is controlled by external incentives and discipline); introjected regulation (when values are absorbed from environment, however, they are not yet perceived as the person's "self-being"); identified regulation (when a person perceives values as his or her personal values; when he or 
she lives in accordance with them); integrated regulation (when values are accepted as personal values; when a person tries to link them to other personal values) (Deci \& Ryan, 1990). According to Hardy et al. (2008), the highest peak of value internalisation is achieved when personal values turn into his or her "self-being", his or her identity, when behaviour derives from the inner faith. It can be said that when moral values are accepted as personal values, then morally responsible actions of adolescents can be expected.

In summary, the purpose of the current study was to examine the relations between adolescent involvement in sports activities and their moral values internalisation. Additionally, we examined the relationship between the internalisation of moral values by gender and experience in sports activities. Based on the concept of the "bracketed morality" (Bredemeier \& Shields, 1986), which emphasized that morality appropriate in everyday life is partially suspended and egocentrism is more appropriate in a sporting context, and empiric finding supporting this concept (Berdemeier \& Shields, 1986; Kavussanu, Boardley, Sagar, \& Ring, 2013), we hypothesize that adolescents participating in sports activities would be more strongly linked to the more controlled forms of value regulation compared to non-athletes. Prior studies showed that moral values in sport became less important for the adolescent athletes with higher sports experience (Stupuris, Šukys, \& Tilindienè, 2013). It could be related with an increasing pressure from teammates and coaches to contribute to winning (Bardi \& Schwartz, 2013). Increasing pressure could be related with the more controlled motivation which is associated with less likelihood to internalised moral values and prosocial behaviour in sport (Hodge \& Lansdale, 2011). Based on these findings we hypothesize that moral value internalisation index of adolescents with higher sports experience would be less compared to that of adolescents with lower sports experience. Given the dearth of research on this topic, we felt it important to examine this topic in an attempt to provide knowledge that could be useful to both educators and coaches.

\section{METHODS}

Participants. The sample included 385 adolescents (192 girls and 193 boys) between 13 and 16 years of age $(M$ age $=14.6, S D=1.11)$. The participants were recruited from four schools of general education within Kaunas city applying the multistage sampling procedure. Among research participants, $43.4 \%(n=167)$ were involved in competitive sports. Referring to gender, more boys were involved in sports activities compared to girls $(52.3 \%$ of boys $(n=101)$ and $34.4 \%$ of girls $(n=66),(p=.001)$. The studied adolescents had participated in their respective sport for an average of $2.97(S D=1.12)$ years. The data of adolescents' participation in sports activities were divided into two groups based on adolescents' sport experience: $>3$-year experience $(n=62)$, and $\leq 3$-year of sport experience $(n=105)$.

Procedure. The research of schoolchildren was subject to permission of school directors and verbal consent of schoolchildren that had to be obtained prior to the research. After the successful agreement with the school administration and arrangement of survey time the researchers arrived to place. The survey was carried out in classrooms during lessons. The teacher of the schoolchildren or the school's deputy director were participating in the survey Prior to each survey the schoolchildren were explained the research purpose and instruction of the questionnaire filling. Emphasis was always given to the survey anonymity and possibility to refuse to participate in the survey at any time.

Measures. Internalisation of moral values was assessed using the 24-item adolescent-report Moral Values Internalisation Questionnaire (Hardy et al., 2008) which was based on the Self-Determination Theory approach to internalisation (Deci \& Ryan, 1990) and Prosocial Self-Regulation Questionnaire (Ryan \& Connell, 1989). The questionnaire contained six questions with four answer options. As the questionnaire measures the internalisation of moral values, two questions were associated with fairness, two questions were associated with honesty, and two questions - with the value of kindness. Each question asked the participants to rate the importance of different reasons why they might or might not engage in certain behaviour, on a scale from 1 - not at all important to 5 very important. The four items for each question represented the four forms of value regulation. Therefore, in total, six items for external regulation $(\alpha=79)$, six items - for introjected regulation $(\alpha$ $=.82)$, six items - for identified regulation $(\alpha=.84)$, and six items - for integrated regulation $(\alpha=.82)$ were represented. For example, a question reflecting a value of honesty was "How important is each of the following reasons for why you might decide to tell the truth when given an opportunity to lie?" 
There were four reasons (items) corresponding to external regulation of values ("Because I wouldn't want to get into trouble for lying"), introjected regulation of values ("Because I would not want people to think of me as a liar"), identified regulation of values ("Because I think telling the truth is the right thing to do"), and integrated regulation of values ("Because I consider myself an honest person").

Composite scores for each level of internalisation (i.e. each form of value regulation) were created by calculating the mean of the six items corresponding to each level. Additionally, a composite of overall internalisation was calculated by differentially weighing individual composite scores on the four levels ( -2 for external, -1 for introjected, +1 for identified and +2 for integrated), as suggested by Grolnick and Ryan (1989). This relative autonomy composite is a score that indicates the degree to which adolescents prefer using more internalized modes of value regulation (identified and integrated) compared to less internalized modes of value regulation (external and introjected).

Adolescents' participation in sport was assessed using the question "Do you participate in competitive sports?" with response alternatives. This question measuring participation in sports was validated in the earlier studies with adolescents (Šukys, 2004). Therefore, in data analysis the subjects were divided into two groups: athletes (those persons who attended sports at schools or clubs for no less than two hours per week and participated in competitions, and these activities continued no less than one year) and non-athletes.

Data analysis. All the analyses were performed using IBM SPSS Statistics for Windows software (version 19.0). The analysis included Cronbach's alpha coefficients, descriptive statistics, Pearson's correlations, and distribution of data (including Skew and Kurtosis) calculation. The statistical or null hypothesis (Ho) of equality of the mean (M) between groups was tested using independent sample $t$-test and One-Way ANOVA. In all instances (comparing more than two groups) where the Ho was rejected, post-hoc (Tukey's test) was computed. For analyses of variance the effect size was calculated: $\eta^{2}=$ Sum of squares between groups/ Total sum of squares. In interpreting effect size the guidance from Cohen (1988) was taken into account: $0.01-0.05$ a very small effect, $0.06-$ 0.14 a moderate effect and from 0.15 a very large effect. Comparing two groups Cohen's d effect size was calculated.

\section{RESULTS}

Descriptive statistics and correlations were computed using the entire sample and presented in Table 1. The adolescents reported identified regulation more, followed by introjected regulation, integrated regulation, and external regulation, respectively. Significant correlations were determined between all levels of internalisation.

One-way ANOVA showed the difference in external regulation between the three groups of adolescents by their involvement in sports activities (Table 2). Tukey's HSD tests demonstrated that the adolescents participating in sport less than 3 years scored statistically significantly higher than the group of adolescents not participating in sport $(p=.017)$. ANOVA indicated the differences in introjected regulation between the three groups of adolescents. Tukey's HSD tests showed that the adolescents participating in sport less than 3 years scored statistically significantly higher than the group of adolescent non-athletes $(p=.006)$. One-way ANOVA revealed a significant difference between the identified regulation means. Tukey's HSD tests showed that the adolescents participating in sport less than 3 years scored statistically significantly higher than the group of adolescent non-athletes $(p=.019)$. Additionally, the analysis of variance identified differences in integrated

\begin{tabular}{|c|c|c|c|c|c|c|c|c|}
\hline \multirow{2}{*}{ Variables } & \multirow{2}{*}{$M$} & \multirow{2}{*}{$S D$} & \multirow{2}{*}{$\begin{array}{l}\text { Skew/ } \\
\text { kurtosis }\end{array}$} & \multicolumn{5}{|c|}{ Correlation } \\
\hline & & & & 1 & 2 & 3 & 4 & 5 \\
\hline 1. External regulation & 3.82 & 0.79 & $-1.04 / 1.49$ & $(.79)$ & & & & \\
\hline 2. Introjected regulation & 3.93 & 0.81 & $-1.14 / 1.55$ & $.79 * *$ & $(.82)$ & & & \\
\hline 3. Identified regulation & 4.05 & 0.79 & $-1.23 / 1.80$ & $.73 * *$ & $.81 * *$ & $(.84)$ & & \\
\hline 4. Integrated regulation & 3.89 & 0.77 & $-1.14 / 1.82$ & $.64 * *$ & $.73 * *$ & $.74 * *$ & $(.82)$ & \\
\hline 5. Overall internalization & 0.25 & 1.49 & $-0.1 / 1.49$ & $-.45 * *$ & $-.21 * *$ & .08 & $.35 * *$ & $(.94)$ \\
\hline
\end{tabular}

Table 1. Correlations, reliability estimates, and descriptive statistics for moral value internalization $(N=385)$

Notes. ${ }^{* *} p<.01$. Alpha coefficients are reported on the diagonal. 
Table 2. Means, SD, and effect size of adolescents moral values internalization by the involvement in sport activities $(N=385)$

\begin{tabular}{|c|c|c|c|c|c|c|c|c|c|}
\hline \multirow[t]{2}{*}{ Variable } & \multicolumn{2}{|c|}{ Any sports } & \multicolumn{2}{|c|}{$\begin{array}{c}>3 \text { year } \\
\text { experience }\end{array}$} & \multicolumn{2}{|c|}{$\begin{array}{c}\leq 3 \text { year } \\
\text { experience }\end{array}$} & \multirow{2}{*}{$F(2.384)$} & \multirow{2}{*}{$p$} & \multirow[t]{2}{*}{$\eta^{2}$} \\
\hline & $M$ & $S D$ & M & SD & $\mathbf{M}$ & SD & & & \\
\hline External regulation & 3.73 & 0.84 & 4.06 & 0.69 & 3.85 & 0.74 & 3.90 & .021 & .020 \\
\hline Introjected regulation & 3.84 & 0.88 & 4.21 & 0.51 & 3.92 & 0.77 & 4.82 & .009 & .031 \\
\hline Identified regulation & 3.96 & 0.85 & 4.27 & 0.58 & 4.09 & 0.76 & 3.91 & .021 & .020 \\
\hline Integrated regulation & 3.79 & 0.82 & 4.13 & 0.57 & 3.95 & 0.73 & 5.51 & .004 & .028 \\
\hline Overall internalization & 0.21 & 1.51 & 0.22 & 1.51 & 0.37 & 1.17 & 0.46 & .634 & .001 \\
\hline
\end{tabular}

Table 3. Means, SD, and effect size of adolescents girls moral value internalization by the involvement in sports activities $(n=66)$

\begin{tabular}{|c|c|c|c|c|c|c|c|c|c|}
\hline \multirow[t]{2}{*}{ Variable } & \multicolumn{2}{|c|}{ Any sports } & \multicolumn{2}{|c|}{$\begin{array}{c}>3 \text { year } \\
\text { experience }\end{array}$} & \multicolumn{2}{|c|}{$\begin{array}{c}\leq 3 \text { year } \\
\text { experience }\end{array}$} & \multirow[t]{2}{*}{$F(2.191)$} & \multirow[t]{2}{*}{$p$} & \multirow[t]{2}{*}{$\eta^{2}$} \\
\hline & $M$ & $S D$ & M & SD & M & SD & & & \\
\hline External regulation & 3.98 & 0.72 & 4.23 & 0.56 & 3.98 & 0.84 & 1.73 & .180 & .018 \\
\hline Introjected regulation & 4.02 & 0.79 & 4.29 & 0.42 & 4.08 & 0.85 & 1.73 & .179 & .018 \\
\hline Identified regulation & 4.17 & 0.75 & 4.39 & 0.51 & 4.26 & 0.75 & 1.25 & .290 & .013 \\
\hline Integrated regulation & 3.92 & 0.73 & 4.11 & 0.51 & 4.08 & 0.80 & 1.32 & .269 & .014 \\
\hline Overall internalization & 0.03 & 1.37 & -0.15 & 1.58 & 0.38 & 1.96 & 1.08 & .341 & .011 \\
\hline
\end{tabular}

Table 4. Means, SD, and effect size of adolescents boys moral value internalization by the involvement in sports activities $(n=101)$

\begin{tabular}{|c|c|c|c|c|c|c|c|c|c|}
\hline \multirow[t]{2}{*}{ Variable } & \multicolumn{2}{|c|}{ Any sports } & \multicolumn{2}{|c|}{$\begin{array}{c}>3 \text { year } \\
\text { experience }\end{array}$} & \multicolumn{2}{|c|}{$\begin{array}{c}\leq 3 \text { year } \\
\text { experience }\end{array}$} & \multirow[t]{2}{*}{$F(2.192)$} & \multirow[t]{2}{*}{$p$} & \multirow[t]{2}{*}{$\eta^{2}$} \\
\hline & $M$ & $S D$ & $M$ & $S D$ & $M$ & $S D$ & & & \\
\hline External regulation & 3.41 & 0.89 & 3.84 & 0.78 & 3.79 & 0.69 & 5.80 & .004 & .057 \\
\hline Introjected regulation & 3.61 & 0.94 & 4.10 & 0.60 & 3.86 & 0.73 & 4.45 & .013 & .045 \\
\hline Identified regulation & 3.68 & 0.90 & 4.13 & 0.64 & 4.02 & 0.75 & 5.27 & .006 & .053 \\
\hline Integrated regulation & 3.60 & 0.91 & 4.16 & 0.65 & 3.89 & 0.70 & 6.30 & .002 & .062 \\
\hline Overall internalization & 0.45 & 1.66 & 0.67 & 1.31 & 0.37 & 1.20 & 0.45 & .640 & .005 \\
\hline
\end{tabular}

regulation means. Post hoc analysis revealed that adolescents participating in sport less than 3 years scored statistically significantly higher than the group of adolescents not participating in sport $(p=.005)$.

Additionally we performed analyses separately in the girls' and boys' samples. It should be noted that there were no statistically significant differences comparing internalisation of moral values in girls' groups (Table 3). Otherwise, comparing the boys' groups, the study showed the relationship between involvement in sports activities and their moral value internalisation. One-way ANOVA showed the difference in external regulation between the three groups of adolescents by their involvement in sports activities (Table 4). Tukey's HSD tests showed that adolescent non-athletes scored significantly lower than the adolescent boys participating in sport up to $3(p<.05), 3$ and more years $(p<.01)$. ANOVA indicated the differences in introjected regulation between the three groups of adolescents. Tukey's HSD tests showed that the adolescents participating in sport up to 3 years scored statistically significantly higher than the group of adolescent non-athletes $(p<.05)$. Oneway ANOVA revealed a significant difference between the identified regulation means. Tukey's HSD tests showed that the adolescent non-athletes scored significantly lower comparing to both athlete groups $(p<.05)$. Additionally, the analysis of variance showed differences in integrated regulation means. Post hoc analysis revealed that adolescent non-athletes scored significantly lower compared to boys involved in sports for less than 3 years $(p<.01)$ and those competing 3 years and longer $(p<.01)$.

\section{DISCUSSION}

The research focused on adolescents' internalisation of moral values according to the Self-Determination Theory. Research aim was to examine the relations between adolescents' involvement in sports activities and their moral value internalisation. Research results demonstrated that identified regulation manifested more than other regulations (external, introjected and integrated). It means that individuals accept values as their 
own by identifying with the importance of values and behaviours they dictate. As Deci and Ryan (1990) state "when the person has identified with the regulatory structure, there is less experience of pressure and conflict and less salience of guilt and anxiety" (p. 256). On the other hand, introjected regulation, which refers to extrinsic motivation more when a person does not fully accept values as one's one and own actions are still associated with expectations of self-approval, expresses alike integrated regulation that refers to the most selfdetermined form of internalised regulation. Neither extrinsic nor intrinsic regulations can be attributed to adolescents of the studied age in reference to this research results. This may be explained by the age of participants as socialization process develops resulting in the integration of moral principles and individual values at this particular age (Paciello et al., 2013).

The internalisation of moral values results in value integration and acceptance according to Deci and Ryan (1990) “...bring them into a consistent relation to the other needs, processes, and values that represent self" (p. 255). Since environment is important in this process, we compared moral values of athletes and non-athletes in this study. It was hypothesized that adolescents participating in sports activities would be more strongly linked to the more controlled forms of value regulation compared to those of non-athletes. The results only partly confirmed this hypothesis because adolescent athletes possessed higher scores in the internalisation of moral values in all regulations than non-athletes. In addition, the introjected and integrated regulations of adolescent athletes were higher, which represented greater autonomous forms of regulations. However, in the analysis of these results it is necessary to take into account sports experience because the moral values internalisation forms of adolescent athletes with more than three years of sports experience did not differ compared to those of non-athletes. It shows that the moral value internalisation of adolescent athletes with more sports experience is worse than that of athletes with two-three years of sports experience. These results partially reveal that the first hypothesis had not been completely wrong, and also confirms the other hypothesis that moral value internalisation of adolescents with higher sports experience would be lower compared to that of adolescents with lower sports experience.

The scientific literature is not abundant with studies where internalisation of values is analysed with respect to sports experience of adolescents although some studies analyse athletes' internalisation of values. For instance, the research of adolescents' values (Lee at al., 2008) found that the most important values were based on inner personal experiences: enjoyment, personal achievement, sportsmanship, contract maintenance. Moreover, other studies revealed that the typical motives of children's involvement in sports activities were to have fun, enjoy being physically active with friends (Sit \& Lindner, 2006). Satisfaction and fun were more related with intrinsic motivation. However, extrinsic motives were more related to material rewards (Webb, 2008). Thus, while interpreting the moral value internalisation of adolescents with different sports experience, attention should be focused on several factors linked with the same activity. Motives and objectives in sports activities differentiate together with sporting experience. When winning becomes the most important goal, motives of joy and enjoyment become of lower importance (Webb, 2008). Additionally, the role of a coach is essential in creating a motivational climate in a team. Athletes positively value when the coach builds a task-oriented motivational climate which is related to various positive consequences as enjoyment and effort. Conversely, some studies show that coaches create an ego-oriented motivational climate that is related to emphasis on winning (Almagro, SaenzLopez, Moreno-Murcia, \& Spray, 2015) and on less autonomous motivation of athletes. In turn, the egoorientated motivation does not relate with moral values (Lee at al., 2008) as controlling coaching style does not relate with athletes' autonomous motivation and their moral behaviour (Hodge \& Lonsdale, 2011).

Discussing the differences of internalisation of moral values, it is worth noting that they partly confirm the studies which found that athletes with lower sport experience emphasized moral values more (Stupuris, Šukys, \& Tilindienè, 2013). This is complemented by the research, which focused on the moral behaviour of athletes. The research of athletes' fear of failure and interpersonal antisocial behaviour in educational setting and sport determined that sports experience positively predicted antisocial behaviour in university and sport, and the strength of these predictions did not differ between males and females (Sagar, Broardley, \& Kavussanu, 2011). Nevertheless, the studies should be mentioned when athletes gain more experience in their sports, moral and 
competence values become more important to them, but later their significance decreases (Šukys \& Jansoniené, 2012) or athletes' moral reasoning is not related to sports experience (Proios, Doganis, \& Athanailidis, 2004). Commenting on the results of different studies it may be claimed that in accordance with the Self-Determination Theory athletes could experience different styles of regulation (Almagro et al., 2015).

The research takes into consideration the moral values of the internalisation with respect to gender. It was found that girls' scores in moral values were higher than those of boys, but the overall moral value internalisation was more common in boys. Lee at al. (2013) who analysed which sport values were most important to young people claimed that girls were seen to attach less importance to sporting values than boys, sporting values appeared to become less important with aging but were more important at higher levels of performance. It is also argued that such differences may be influenced by the fact that adolescent girls were less engaged in sports activities than boys, the girls' interests in both general and sporting context varied. Gender differences were also identified in the analysis of moral decisions (Kavussanu \& Roberts, 2001, Sage \& Kavussanu, 2007).

In summary, it can be claimed that sports educators and coaches working with children and adolescents should take into account the creation of sports environment context. Since this age is particularly important in their socialization processes, an environment in the context of sporting activities must be guided not only placing emphasis on winning. In addition, it is important to use a sporting environment promoting the autonomous motivation of young athletes as it is more important for intrinsic processes of value internalisation. It should also be acclaimed that the results may be of interest to parents of athletes.

Strengths and limitations. The pattern of results reported provides important insights into the adolescents' internalisation of moral values ant its relationship with involvement in sports activities. The study showed that adolescents tended to use each of the four forms of value regulation (external, introjected, identified and integrated). Specifically, it seems that involvement in sport may play a role in the internalisation of moral values.

Despite the interesting findings regarding the relations between adolescents' involvement in sports activities and their moral values, there were several limitations to the present study. First, the study was carried out using a cross-sectional design, limiting our ability to draw causal inferences from the results. The second limitation of the current study is a relatively small sample size, which might account for some of the non-significant findings. The third limitation as continuum of the second is that we did not analyse the group of adolescents not participating in sports activities, i. e. which active leisure forms they were engaged in.

\section{CONCLUSION}

The research results demonstrated that the identified regulation was expressed more than other regulations (external, introjected and integrated). The research results only partially confirmed the hypothesis that adolescents participating in sports activities would be more strongly linked to more controlled forms of value regulation compared to non-athletes as adolescent athletes possessed higher scores of moral value internalisation in all regulations than non-athletes. However, given the sports experience, we observed that moral value internalisation forms of adolescent athletes with more than the 3-year sports experience did not differ from those of adolescent non-athletes. Considering gender, a relationship was found between internalisation of values and participation in sport in the sample of boys, but not in the sample of girls.

\section{REFERENCES}

Almagro, B. J., Saenz-Lopez, P., Moreno-Murcia, J. A., \& Spray, Ch. (2015). Motivational factors in young Spanish athletes: A qualitative focus drawing from Self-Determination Theory and Achievement Goal Perspectives. The Sport Psychologist, 29, 15-28.

Bardi, A., \& Schwarz, S. H. (2013). How does the value structure underlie value conflict? In J. Whitehead, H. Telfer, \& J. Lambert (Eds.), Values in Youth Sport and Physical Education (pp. 137-151). London and New York, NY: Routledge.
Barni, D., Ranieri, S., Scabini, E., \& Rosnati, R. (2014). Value transmission in the family: Do adolescents accept the values their parents want to transmit? Journal of Moral Education, 40, 105-121. doi:10.1080/03057240 .2011 .553797

Blomfield, C., \& Barber, B. (2010). Australian adolescents' extracurricular activity participation and positive development: Is the relationship mediated by peer attributes? Australian Journal of Educational \& Developmental Psychology, 10, 108-122. 
Bredemeier, B. J., \& Shields, D. L. (1986). Game reasoning and interactional morality. The Journal of Genetic Psychology, 147, 257-275. doi:10.1080/00221 325.1986.9914499

Budreikaitè, A., \& Adaškevičiene, E. (2010). Sportuojančių ir nesportuojančių paauglių požiūris i vertybes ir jų prasmès suvokimą. Ugdymas. Kūno kultūra. Sportas, 1(76), 13-20.

Cohen, J. (1988). Statistical power analysis for the behavioral sciences (2nd ed.). Hillsdale, NJ: Lawrence Earlbaun Associates.

Deci, E. L., \& Ryan, R. M. (1990). A motivational approach to self: Integration in personality. In R. A. Dienstbier (Ed.), Perspectives on motivation (pp. 237288). Lincoln, NE: University of Nebraska Press.

Esteban-Cornejo, I., Gomez-Martinez, S., TejeroGonzalez, C. M., Castillo, R., Lanza-Saiz, R., VicenteRodriguez, G., Marcos, A., \& Martinez-Gomez, D. (2014). Characteristics of extracurricular physical activity and cognitive performance in adolescents. The AVENA study. Journal of Sports Science, 32, 15961603. doi: 10.1080/02640414.2014.910607.

Grolnick, W. S., Deci, E. L., \& Ryan, R. M. (1997). Internalisation within the family: The Self-Determination Theory perspective. In J. E. Grusec \& L. Kuczynski (Eds.), Parenting and children's internalisation of values: A handbook of contemporary theory (pp. 135161). New York: John Wiley \& Sons.

Grolnick, W. S., \& Ryan, R. M. (1989). Parent styles associated with children's self-regulation and competence in school. Journal of Educational Psychology, 81(2), 143-154.

Grusec, J. E. (2002). Parenting socialization and children's acquisition of values. In M. H. Bornstein (Ed.), Handbook of parenting: Practical issues in parenting (pp. 143-167). Mahwah: Lawrence Erlbaum Associates.

Guevrement, A., Findlay, L., \& Kohen, D. (2014). Organized extracurricular activities: Are in-school and out-of-school activities associated with different outcomes for Canadian youth? Journal of School Health, 84, 317-325. doi:10.1111/josh.12154.

Hardman, A., Jones, C., \& Jones, R. (2010). Sports coaching, virtue ethics and emulation. Physical Education and Sport Pedagogy, 15, 345-359. doi:10.1080/17408980903535784

Hardy, S. A., \& Carlo, G. (2011). Moral identity: What is it, how does it develop, and is it linked to moral action? Child Development Perspectives, 5, 212-218. doi:10.1111/j.1750-8606.2011.00189.x

Hardy, S. A., \& Carlo, G. (2005). Religiosity and prosocial behaviours in adolescence: The mediating role of prosocial values. Journal of Moral Education, 34, 231-249. doi:10.1080/03057240500127210

Hardy, S. A., Padilla-Walker, L. M., \& Carlo, G. (2008). Parenting dimensions and adolescents' internalisation of moral values. Journal of Moral Education, 37, 205-223. doi:10.1080/03057240802009512
Hodge, K., \& Lonsdale, Ch. (2011). Prosocial and antisocial behavior in sport: The role of coaching style, autonomous vs. controlled motivation, and moral disengagement. Journal of Sport \& Exercise Psychology, 33(4), 527-547.

Jankauskiene, R., \& Sukys, S. (2012). Students' behaviour and attitudes to school rules as outcome of involvement in structured leisure activities. In Sabiedrība, integrācija, izglītība: Starptautiskās zinātniskās konferences materiāli, Rēzekne (pp. 278287). Latvia, Rēzekne: Rēzeknes Augstskola.

Kavussanu, M., Boardley, I. D., Sagar, S.S., \& Ring, Ch. (2013). Bracketed morality revisited: How do athletes behave in two contexts? Journal of Sport \& Exercise Psychology, 35, 449-463.

Kavussanu, M., \& Roberts, G. C. (2001). Moral functioning in sport: An achievement goal perspective. Journal of Sport \& Exercise Psychology, 23, 37-54.

Lee, M. J., \& Cockman, M. (1995). Values in children's sport: Spontaneously expressed values among young athletes. International Review of the Sociology of Sport, 30(3/4), 337-348.

Lee, M. J., Whitehead, J., \& Balchin, N. (2013). Which sport values are most important to young people? The measurement of values in youth sport: Development of the Youth Sport Values Questionnaire. In J. Whitehead, H. Telfer, and J. Lambert (Eds.), Values in youth sport and physical education (pp. 49-65). Routledge.

Lee, M. J., Whitehead, J., Ntoumanis, N., \& Hatzigeorgiadis, A. (2008). Relationships among values, achievement orientations, and attitudes in youth sport. Journal of Sport and Exercise Psychology, 30, 588-610.

Mathur, S. S. (2011). Educational psychology, Twentieth Revised Edition. Agra: Agrawal Publication.

Moreno, J. A., \& Cervello, E. (2005). Physical selfperception in Spanish adolescents: Effects of gender and involvement in physical activity. Journal of Human Movement Studies, 48, 291-311.

Myers, D. G. (2000). Psichologija. Kaunas: Poligrafija ir informatika.

Paciello, M., Fida, R., Tramontano, C., Cole, E., \& Cerniglia, L. (2013). Moral dilemma in adolescence: The role of values, prosocial moral reasoning and moral disengagement in helping decision making. European Journal of Developmental Psychology, 10, 190-205. do i:10.1080/17405629.2012.759099

Perenyi, S. (2010). The relation between sport participation and the value preferences of Hungarian youth. Sport in Society, 13(6), 984-1000.

Popescu, V. (2012). Role of sport activities in the formation of eticho moral values. Sport şi Societate, 12(2), 184-189.

Proios, M., Doganis, G., \& Athanailidis, I. (2004). Moral development and form of participation, type of sport, and sport experience. Perceptual and Motor Skills, 99, 633-642. doi:10.2466/pms.99.2.633-642

Ryan, R. M., \& Connell, J. P. (1989). Perceived locus of causality and internalisation: Examining reasons 
for acting in two domains. Journal of Personality and Social Psychology, 57(5), 749-761.

Sagar, S. S., Boardley, I. D., \& Kavussanu, M. (2010). Fear of failure and student athletes' interpersonal antisocial behaviour in education and sport. British Journal of Educational Psychology, 81, 391-408. doi: 10.1348/2044-8279.002001

Sage, L., \& Kavussanu, M. (2007). Multiple goal orientations as predictors of moral behavior in youth soccer. The Sport Psychologist, 21,417-437.

Schwartz, S. H. (1994). Are there universal aspects in the structure and content of human values? The Journal of Social Issues, 50(4), 19-45.

Sit, C. H., \& Lindner, K. J. (2006). Situational state balances and participation motivation in youth sport: A reversal theory perspective. British Journal of Educational Psychology, 76, 369-384. doi: 10.1348/000709905X37190

Stupuris, T., Šukys, S., \& Tilindienè, I. (2013). Relationship between adolescent athletes' values and behavior in sport and perceived coach's character development competency. Education. Physical Training. Sport, 91(4), 37-45.
Šukys, S. (2004). Interrelation among behavioral decisions of adolescents, their gender and physical activity. Education. Physical Training. Sport, 4, 89-94.

Šukys, S., \& Jansonienė, A. J. (2012). Relationship between athletes' values and moral disengagement in sport, and differences across gender, level and years of involvement. Education. Physical training. Sport, 84(1), 55-61.

Timpau, C. (2015). The role of moral values in development personality teenagers. Revista Romaneasca pentru Educatie Multimensionala, 7(1), 75-88.

Vaitkevičius, V., Miliūnienè, L., Bakanovienė, T. (2008). Neformalaus ugdymo organizavimas mokykloje ir už jos ribų: mokinių požiūrio analizè. Jaunujų mokslininku darbai, 4(20), 252-257.

Webb, L. J. (2008). Coaching complexities: Youth sports. Journal of Youth Sports, 4(1), 24-29.

Whitehead, J., \& Goncalves, C. E. (2013). Are sport values similar in other nations? Exploring cross-cultural value system. In J. Whitehead, H. Telfer, and J. Lambert (Eds.), Values in youth sport and physical education (pp. 104-118). Routledge. 